\title{
THE INFLUENCE OF KAPPA-CASEIN AND BETA-LACTOGLOBULIN GENOTYPES ON MILK COAGULATION PROPERTIES IN LATVIA DAIRY BREED
}

\author{
Solvita Petrovska, Daina Jonkus, Jelena Zagorska, Inga Ciprovica \\ Latvia University of Agriculture \\ solvitapetrovska@inbox.lv
}

\begin{abstract}
Milk yield, composition and milk coagulation properties can be affected by kappa-casein $(\kappa-\mathrm{CN})$ and beta-lactoglobulin ( $\beta$-LG) genotypes and breed. Latvian Brown (LB) and Latvian Blue (LZ) are local dairy breeds in Latvia. These breeds are not so high-yielding than other commercial dairy breeds, besides, the number of those animals decrease each year. The aim of the research was to analyze the influence of $\kappa-\mathrm{CN}, \beta-\mathrm{LG}$ and breed on milk composition and milk coagulation properties. Data were collected from 56 Latvian Brown and 26 Latvian Blue in 2016. Widespread $\kappa-\mathrm{CN}$ genotype was AA (0.593) in LB breed and $\mathrm{AB}(0.636)$ in LZ breed, while $\beta$-LG highest frequency was $\mathrm{BB}$ genotype. Significant effect was not observed on milk yield, however the highest daily milk yield was from $\mathrm{AB} \kappa-\mathrm{CN}$ genotype $(19.7 \pm 1.52 \mathrm{~kg})$ in LB breed. Significant differences were observed in fat content - the highest fat content accordingly $\kappa-\mathrm{CN}$ was from AA genotype in LB $\left(46.3 \pm 1.89 \mathrm{~g} \mathrm{~kg}^{-1}\right)$ and $45.5 \pm 1.37 \mathrm{~g} \mathrm{~kg}^{-1}$ from BB $\beta$-LG genotype in LB breed $(\mathrm{p}<0.05)$. A lower protein content was observed from AA $\kappa-C N$ genotype in LZ breed $(33.8 \pm 1.30 \mathrm{~g}$ $\mathrm{kg}^{-1}$ ), while highest from BB genotype in both breeds. Curd firmness was not significantly different by genotypes and breed. Significantly shorter milk renneting time of $\beta$-LG was obtained from LB breed $(14.6 \pm 2.76 \mathrm{~min}, \mathrm{p}<0.05)$, while $\kappa-\mathrm{CN}$ genotype was not significantly affected.
\end{abstract}

Key words: milk coagulation properties, kappa-casein, beta-lactoglobulin.

\section{Introduction}

Beta-lactoglobulin $(\beta-\mathrm{LG})$ and kappa-casein $(\kappa-$ $\mathrm{CN})$ are two of the most important proteins in the milk of mammals (Flower, 1996). During the past 70 years, $\beta$-lactoglobulin has been studied by every available biochemical technique (Flower, North, \& Sansom, 2000). The concentration of $\beta-\mathrm{LG}$ in bovine milk varied from 2 to $3 \mathrm{~g} \mathrm{~kg}^{-1}$ (Kontopidis, Holt, \& Sawyer, 2004). Messenger RNA coding $\beta-\mathrm{LG}$ is synthesized in the mammary gland, and $\beta$-LG contains residues of 162 amino acids. Main alleles are A and B for coding this protein and only two amino acids are different. Aspartic acid is substituted with glycine at position 64 and valine with alanine at position 118 (Qin et al., 1999). Casein is milk protein which contains four casein fractions $-\alpha_{\mathrm{s} 1}$-casein, $\alpha_{\mathrm{s} 2}$-casein, $\beta$-casein and $\kappa$-casein. Two genetic $\kappa-\mathrm{CN}$ variants are more widespread $-\mathrm{A}$ and $\mathrm{B}$. A variant has a threonine at position 136 and an aspartic acid at position 148 of the mature protein, while $\mathrm{B}$ variant has isoleicin and alanine residues at these positions, respectively (Alexander et al., 1988).

The coagulation ability of milk is essential for cheese making. Milk with favorable coagulation properties (short coagulation and curd firming time and a firm curd) is expected to give more cheese with desirable composition than milk with unfavorable properties. Scientists have found that $8 \%$ of milk samples do not coagulate during 30 min and haveanalyzed the factors which affect milk coagulation. Several researchers found that parity did not affect coagulation properties, but some authors found the opposite effect (Lindström, Antila, \&
Syväjarvi, 1984; Davoli, Dall'Olio, \& Russo, 1990).

According to the results of the previous studies from Tsiaras and co-authors (2005), A of $\beta$-LG allele is more prevalent than B allele - it was found that genotype frequencies were $0.28,0.47$ and 0.25 for $\mathrm{AA}, \mathrm{AB}$ and $\mathrm{BB}$ genotypes $\beta$-LG. A similar tendency was found by Kučerová et al., (2006). Scientists from Estonia found that A allele frequencies were 0.188, 0.138 and 0.319 for Estonian native, Estonian Red and Estonian Holstein, but B allele was found with frequency $0.813,0.863$ and 0.681 , respectively (Värv et al., 2009). According to the studies of Ren and his colleagues (2011), A allele and AA genotype of $\kappa-\mathrm{CN}$ are more widespread in Holstein and other highyield dairy breeds, while the opposite situation was obtained for Jersey breed. The frequency of AA $\kappa-\mathrm{CN}$ genotype was 0.55 in Holstein, while this genotype was not observed in Jersey breed, but BB genotype of $\kappa-\mathrm{CN}$ with frequency 0.77 was observed in Jersey (Ren et al., 2011).

Schaar and co-authors (1985) found that the milk coagulation time was shorter for the $\beta$-LG BB genotype ( $p<0.001$ ), while the curd firmness was not affected by the $\beta$-LG genotypes. The $\beta$-LG AA genotype had a favorable effect on milk coagulation properties in some studies (Schaar, Hansson, \& Pettersson, 1985; Aleandri et al., 1990 Ikonen et al., 1999; Wedholm et al., 2006). Pečiulaitiené and co-authors (2007) observed the highest milk yield and fat content from cows with AB genotype. Ng-Kwai-Hang and coauthors $(1984,1986)$ and Tsiaras with colleagues (2005) described the genotype $\kappa$-CN effect on milk yield, composition and milk coagulation properties. 
Animals with $\mathrm{AB}$ and $\mathrm{BB} \kappa$-casein genotypes have the highest protein content and better milk coagulation properties.

Previous studies in Latvia have not described milk coagulation properties according to $\kappa$-casein and $\beta$-lactoglobolin genotypes.

The purpose of our research was to analyze $\kappa-\mathrm{CN}$ and $\beta$-LG genotypes and breed influence on milk composition and coagulation properties.

\section{Materials and Methods}

Data, blood samples and individual milk samples were collected from Latvian cow breeds (56 Latvian Brown (LB), 26 Latvian Blue (LZ)) from different regions of Latvia in 2016. Milk samples were collected during summer (July to August, 2016) period.

All cows were kept in small farms - on average 6 animals in each farm. Analyzed cows were grazed on pastures; grain meal and mineral additives were fed to them. LB cows were in $136 \pm 8.1$ lactation day and $\mathrm{LZ}-144 \pm 9.7$ lactation day. Cows were milked twice. Average LB cows were $3.1 \pm 0.17$ parity and $L Z-3.5$ \pm 0.26 parity.

The blood samples were taken from the jugular vein (Vena jugularis) and collected in the $\mathrm{K}_{3}$-EDTA coated sterile vacutainers, and stored at $-20{ }^{\circ} \mathrm{C}$ until DNA extraction. The research was conducted at the Scientific Laboratory of Molecular Biology and Microbiology of Latvia University of Agriculture.

DNA was extracted by Genomic DNA Purification Kit\# KO512 and DNEasy Blood@Tissue Kit (Fermentas, Lithuania) which was extracted by QIAcube (QIAcube, USA). $\beta-\mathrm{LG}$ alleles were identified using The PCR-RELP (Polymerase Chain Reaction and Restriction Fragment Length Polymorphism) according to Medrano and Aguilar Cordova (1990) method.

Kappa-CN genotypes were identified using PCR-RFLP and electrophoresis on 3\% agarose gel. The identification of $\kappa-\mathrm{CN}$ single nucleotide polymorphisms (SNPs) was done by methodology of Velmala et al. (1993). SNPs at positions 13104 and 13124 were examined to determine the nucleotide changes $(A->C$ and $A->G)$, which analyse $\kappa-C N$ alleles $\mathrm{A}, \mathrm{B}$ and also $\mathrm{E}$. For digestion endonuclease HinfI was used to detect the presence of alleles $\mathrm{A}$ and $\mathrm{B}$, and endonuclease BsuRI (Fermentas, Lithuania) to detect the presence of the allele E.

Protein and fat content, milk density, curd yield and curd firmness, protein and fat ratio were detected at the Faculty of Food Technology of LUU. Protein content was detected according to ISO 8968-1:2014 using KjeltecTM 2100 (Foss, Denmark). Fat content was detected according to ISO 488:2008 using centrifuge (Funke Gerber, Germany). Curd yield (\%) was calculated by weight of curd obtained from milk.
Density of milk was measured according to Latvian Standard 186:1999 using lactodensitometer (Labtajm, Ukraine).

The rennet (CHY-MAX $1000 \mathrm{IMCU} / \mathrm{mL}$, Chr. Hansen, Denmark) used in the analyses of curd firmness was diluted 1:100 (v/v) and added $0.2 \mathrm{~mL}$ to $10 \mathrm{~mL}$ of milk. The curd firmness (in Newton's) was determined after $30 \mathrm{~min}$ of milk renneting at $35{ }^{\circ} \mathrm{C}$ using Texture Analyser TA-HD plus (Stable Micro System, UK). Compression method for determination of curd firmness (technical data - disc $\mathrm{A} / \mathrm{BE}-\mathrm{d} 45$, test speed $1.0 \mathrm{~mm} \mathrm{~s}^{-1}$, distance in the depth of curd sample $8 \mathrm{~mm}$ ) was used.

Renneting time in minutes was analyzed using $1: 100(\mathrm{v} / \mathrm{v})$ of rennet solution into water and measuring the time until flocculation of milk was started at 35 ${ }^{\circ} \mathrm{C}$. For the interpretation of results, all samples were divided into four groups (fast, average, slow and noncoagulating milks) based on the time devoted to the clotting of samples. The assessment of clotting time was the following: fast means flocculation formation during $10 \mathrm{~min}$, average - $15 \mathrm{~min}$, slow - more than $15 \mathrm{~min}$, and non-coagulating - samples that did not coagulate at all.

Analyses of milk composition and coagulation properties were not provided for $\mathrm{AE} \kappa-\mathrm{CN}$ genotype taking into account the low number of cows with this genotype. In tables we have not included data about the milk composition and coagulation properties from cows with non-coagulated milk.

Statistical data processing was carried out using MS Excel and ANOVA of SPSS 15.0 for Windows. The differences between groups were significant if $\mathrm{p}<0.05$ and were marked with letters in superscript $\left({ }^{\mathrm{a}, \mathrm{b}, \mathrm{c}}\right)$ between genotypes and $\left({ }^{\mathrm{A}, \mathrm{B}}\right)$ between breeds.

\section{Results and Discussion}

We observed $\kappa-\mathrm{CN}$ allelic frequencies $0.778,0.213$ and 0.009 for A, B and E allele in LB breed (Table 1). Similar allelic frequencies of $A$ and $B$ alleles were found in LZ breed. E allele was not found in LZ breed. Widespread $\kappa-\mathrm{CN}$ genotype of LB breed was AA with frequency 0.593 , while frequency of $\mathrm{BB}$ genotype was 0.037 . AB $\kappa-\mathrm{CN}$ genotype frequency of $\mathrm{LZ}$ breed was 0.636 , while AA genotype frequency was lower compared with LB breed -0.318 . A similar tendency of $\kappa-\mathrm{CN}$ allelic frequencies was observed by Pärna with colleagues (2007) in Estonian Holstein breed. Estonian native breed $\mathrm{A}, \mathrm{B}$ and $\mathrm{E}$ allelic frequencies were $0.725,0.238$ and 0.038 , respectively (Värv et al., 2009).

$B$ allele of $\beta$-LG genotype was widespread in both breeds - the frequencies were 0.917 and 0.886 , respectively. Accordingly, BB genotype of $\beta-\mathrm{LG}$ was with frequencies 0.852 in LB breed and 0.773 in LZ 
The frequencies of $\kappa-\mathrm{CN}$ and $\beta-\mathrm{LG}$ alleles and genotypes

\begin{tabular}{|l|c|c|c|}
\hline \multirow{3}{*}{ Protein } & \multirow{2}{*}{ Alleles and genotypes } & \multicolumn{2}{|c|}{ Frequencies of alleles and genotypes } \\
\cline { 2 - 4 } & & Latvian Brown $(\mathrm{n}=56)$ & Latvian Blue $(\mathrm{n}=26)$ \\
\hline \multirow{4}{*}{ K-CN } & $\mathrm{A}$ & 0.778 & 0.636 \\
\cline { 2 - 4 } & $\mathrm{B}$ & 0.213 & 0.364 \\
\cline { 2 - 4 } & $\mathrm{E}$ & 0.009 & 0.000 \\
\cline { 2 - 4 } & $\mathrm{AA}$ & 0.593 & 0.318 \\
\cline { 2 - 4 } & $\mathrm{AB}$ & 0.352 & 0.636 \\
\cline { 2 - 4 } & $\mathrm{BB}$ & 0.037 & 0.045 \\
\hline \multirow{3}{*}{-LG } & $\mathrm{AE}$ & 0.019 & 0.000 \\
\cline { 2 - 4 } & $\mathrm{A}$ & 0.083 & 0.114 \\
\cline { 2 - 4 } & $\mathrm{B}$ & 0.917 & 0.886 \\
\cline { 2 - 4 } & $\mathrm{AA}$ & 0.019 & 0.000 \\
\cline { 2 - 4 } & $\mathrm{AB}$ & 0.130 & 0.227 \\
\cline { 2 - 4 } & $\mathrm{BB}$ & 0.852 & 0.773 \\
\hline
\end{tabular}

breed, while frequency of AA genotype was 0.019 and this genotype was not observed in LZ breed. Estonian native and Estonian Red frequencies of B $\beta$-LG allele were 0.813 and 0.863 (Värv et al., 2009).

Significant differences were not observed between $\kappa-\mathrm{CN}$ genotypes and breeds. The highest milk yield was observed from AB $\kappa-C N$ genotype in LB breed $(19.7 \pm 1.52 \mathrm{~kg})$, while a lower milk yield was BB genotype in the same breed (Table 2). Tsiaras et al., (2005) have found the same milk yield tendency - the highest milk yield was from $\mathrm{AB}$ genotype, an average from AA and a lower milk yield was obtained from BB genotype.

A significantly higher fat content was observed from AA genotype in LB breed $\left(46.3 \pm 1.89 \mathrm{~g} \mathrm{~kg}^{-1}\right)$ compared with LZ breed - $38.2 \pm 3.63 \mathrm{~g} \mathrm{~kg}^{-1}(\mathrm{p}<$ $0.05)$. Different results were revealed in Tsiaras et al., (2005) research - the highest fat content was observed from AB genotype. Lunden, Nilsson, \& Janson (1997) had obtained no significant differences in fat content between the AA and $\mathrm{AB}$ genotypes.

Previous papers described a positive effect of $\mathrm{B}$ allele on protein content and protein yield $(\mathrm{Ng}-$ Kwai-Hang et al., 1984; Ng-Kwai-Hang, Monardes, \& Hayes, 1990; Van Eenennaam \& Medrano, 1991; Vallas et al., 2010). We did not find a significant difference, however a tendency appeared. The highest milk protein content was obtained from BB genotype in both breeds, while we found a lower protein content from AA genotype $-33.8 \pm 1.30 \mathrm{~g} \mathrm{~kg}^{-1}$ in $\mathrm{LZ}$ and 34.4 \pm 0.68 in LB milk samples.

The average milk density (Table 2) was $1028 \mathrm{~kg} \mathrm{~m}^{-3}$ in all genotypes and breed, except milk from $\mathrm{LZ}$ cows with $\mathrm{AB}$ genotype. According to the studies of Wangdi and co-authors (2014), the milk density can be affected by breed and vary from 1027 to $1030 \mathrm{~kg} \mathrm{~m}^{-3}$. Milk density influences milk chemical composition especially solids-not-fat (Jasińska et al., 2010).

Curd firmness (Table 2) was not significantly different between breeds, however, the highest curd firmness was obtained from $\mathrm{AB}$ genotype in $\mathrm{LZ}$ breed $(3.35 \pm 0.18 \mathrm{~N})$, while a lower value was $\mathrm{BB}$ genotype in the same breed. Curd firmness is a very important factor, mainly because the amount of milk used for cheese manufacture is growing worldwide, and several works (De Marchi et al., 2008; Wedholm et al., 2006) have confirmed the importance of MCP as well as curd firmness on cheese processing, yield and quality.

In previous studies it was found that breed and genotypes ( $\kappa-\mathrm{CN}$ and $\beta-\mathrm{LG})$ can affect curd firmness significantly (Sturaro et al., 2012; Vallas et al., 2012).

A significantly higher curd yield was observed from BB $\kappa-\mathrm{CN}$ genotype in LB breed $(28.4 \pm 3.89 \%)$ and LZ breed $(28.8 \pm 6.16 \%, \mathrm{p}<0.05)$ compared with genotypes $\mathrm{AA}$ and $\mathrm{AB}$. Allele $\mathrm{B}$ showed a positive effect on curd yield in both breeds. Ng-Kwai-Hang and co-authors (1984) have confirmed that milk obtained from cows with BB genotype has the highest curd yield compared to the milk collected from cows with $\mathrm{AA}$ and $\mathrm{AB} \kappa$-casein genotype.

Milk renneting time (Table 2) was not significantly different between breeds and genotype, however longer time was observed from AB genotype in LZ breed (18.6 $\pm 4.44 \mathrm{~min})$. Zannoni and Annibaldi (1981) recommended that optimal value of milk coagulation time is $13 \mathrm{~min}$. We obtained a closer result from $\mathrm{AB}$ $\kappa-\mathrm{CN}$ in LB breed $-14.9 \pm 1.23 \mathrm{~min}$. Milk renneting time is influenced not only by genotype, but also by 
breed, season, milk composition and $\mathrm{pH}$ (Marchi et al., 2013).

Significant differences in protein to fat ratio were found in $\mathrm{AB}$ and $\mathrm{BB}$ genotypes, as well as in $\mathrm{LZ}$ breed $(p<0.05)$. Composition of the cheese and its yield can be significantly affected by changes in the concentration of protein and fat in milk. According to the study of Guinee and co-authors(2007), a ratio of protein to fat in milk between 0.77 and 0.83 (in case of Latvian Brown) results in a significantly less fat retention during the cheese production compared to cheese produced from milk with a ratio protein to fat between 0.95 and 1.21 (in case of Latvian Blue). The actual cheese yield reducing increased ratio protein to fat in milk and extensive impact was observed on reducing the moisture content of fat free matter, fat in dry matter, salt content (Guinee et al., 2007).

Analyzing influence of $\beta$-LG on milk yield in LB and LZ breeds, we did not observe significant differences. We observed different tendencies in breeds. The highest milk yield was observed from BB $\beta$-LG genotype in LB breed, while the highest milk yield was from $\mathrm{AB}$ genotype in $\mathrm{LZ}$ breed. Matějiček and co-authors (2008) found that the highest milk yield was associated with AA $\beta$-LG genotype.

Significant differences were obtained in fat content ( $<<0.05$; Table 3$)$. A higher fat content was observed in $A B \beta-L G$ genotype in LB compared with LZ breed. Significant differences were obtained in BB genotype - the highest fat content was found in BB genotype LB breed $\left(45.5 \pm 1.37 \mathrm{~g} \mathrm{~kg}^{-1}, \mathrm{p}<0.05\right)$. A positive effect on milk fat content by BB $\beta-L G$ genotype was obtained in the study of Zaglool and coauthors (2016).

Protein content was not significantly different between research groups. The highest protein content was obtained from BB genotype in LZ breed $-35.3 \pm$ $1.19 \mathrm{~g} \mathrm{~kg}^{-1}$.

Milk density was significantly different between LB and LZ breeds in AB $\beta$-LG genotype. The highest density was obtained in LZ breed (1030.4 \pm $1.29 \mathrm{~kg} \mathrm{~m}^{-3}$ ), while lower value was obtained in LB breed $\left(1027.9 \pm 0.14 \mathrm{~kg} \mathrm{~m}^{-3}, \mathrm{p}<0.05\right)$.

Milk coagulation properties are commonly defined by milk renneting time and curd firmness. A short milk coagulation time and a firmer curd are favorable for cheese production (Aleandri, Schneider, \& Buttazzoni, 1989; Martin et al., 1997). Zannoni \& Annibaldi (1981) study has revealed that the optimal milk renneting time is 13 minutes. Closer results we obtained from $\mathrm{AB}$ genotype in LB breed (14.6 \pm 2.76 $\min$ ).

Significant differences were not obtained in curd firmness and curd yield. The highest curd firmness was obtained from $\mathrm{AB}$ genotype in LB breed (3.79 \pm $0.44 \mathrm{~N}$ ), while lower curd firmness was from the same genotype in LZ breed $(2.58 \pm 0.52 \mathrm{~N})$. The highest curd yield was observed from BB genotype $-24 \%$ in both breeds.

A significantly shorter milk renneting time was obtained from $\mathrm{AB}$ genotype in LB breed $(14.6 \pm 2.76$ min), compared with LZ breed $(21.7 \pm 10.35 \mathrm{~min}$, $\mathrm{p}<0.05$ ).

Protein to fat ratio was significantly different between genotypes in LZ breed. The highest protein to fat ratio was obtained from $\mathrm{AB}$ genotype (1.60 $\pm 0.39, \mathrm{p}<0.05)$ and this milk is not favorable for cheese making.

We observed average relationships between milk protein to fat ratio and curd yield. Phenotypical correlation coefficient was $r_{p}=-0.56$ in LB breed and $r_{p}=-0.54$ in LZ breed. According to Bojanić-Rašović

Milk compositions and milk coagulation properties according to $\kappa-\mathrm{CN}$

\begin{tabular}{|l|c|c|c|c|c|c|}
\hline \multirow{2}{*}{\multicolumn{1}{|c|}{ Trait }} & \multicolumn{3}{|c|}{ Latvian Brown } & \multicolumn{3}{c|}{ Latvian Blue } \\
\cline { 2 - 7 } & AA $(\mathrm{n}=32)$ & AB $(\mathrm{n}=19)$ & BB $(\mathrm{n}=2)$ & AA $(\mathrm{n}=7)$ & AB $(\mathrm{n}=13)$ & BB $(\mathrm{n}=2)$ \\
\hline $\begin{array}{l}\text { Daily milk yield, } \\
\text { kg }\end{array}$ & $19.6 \pm 1.04$ & $19.7 \pm 1.52$ & $14.6 \pm 4.65$ & $18.3 \pm 1.14$ & $16.7 \pm 1.95$ & $15.7 \pm 7.67$ \\
\hline Fat, g kg-1 & $46.3 \pm 1.89^{\mathrm{a}}$ & $41.7 \pm 2.04^{\mathrm{a}}$ & $41.0 \pm 3.37^{\mathrm{a}}$ & $38.2 \pm 3.63^{\mathrm{b}}$ & $33.9 \pm 3.24^{\mathrm{b}}$ & $40.0 \pm 5.39^{\mathrm{b}}$ \\
\hline Protein, $\mathrm{g} \mathrm{kg}^{-1}$ & $34.4 \pm 0.68$ & $34.8 \pm 0.81$ & $36.7 \pm 1.55$ & $33.8 \pm 1.30$ & $35.5 \pm 1.45$ & $36.8 \pm 1.48$ \\
\hline Density, kg m${ }^{-3}$ & $1028.1 \pm 0.25$ & $1028.7 \pm 0.25$ & $1028.5 \pm 0.20$ & $1028.7 \pm 0.50$ & $1029.2 \pm 0.67$ & $1028.7 \pm 0.42$ \\
\hline Curd firmness, $\mathrm{N}$ & $3.20 \pm 0.24$ & $3.22 \pm 0.31$ & $3.24 \pm 0.65$ & $3.17 \pm 0.50$ & $3.35 \pm 0.18$ & $2.73 \pm 0.75$ \\
\hline Curd yield,\% & $23.7 \pm 0.94^{\mathrm{a}}$ & $24.0 \pm 1.66^{\mathrm{a}}$ & $28.4 \pm 3.89$ & $21.4 \pm 1.55^{\mathrm{a}}$ & $23.5 \pm 1.35^{\mathrm{a}}$ & $28.8 \pm 6.16$ \\
\hline $\begin{array}{l}\text { Milk renneting } \\
\text { time, min }\end{array}$ & $18.2 \pm 1.99$ & $14.9 \pm 1.23$ & $17.1 \pm 1.39$ & $17.7 \pm 3.99$ & $18.6 \pm 4.44$ & $17.4 \pm 2.84$ \\
\hline Protein to fat ratio & $0.77 \pm 0.03$ & $0.83 \pm 0.06^{\mathrm{a}}$ & $0.77 \pm 0.03^{\mathrm{a}}$ & $0.95 \pm 0.10$ & $1.24 \pm 0.17^{\mathrm{b}}$ & $1.01 \pm 0.08^{\mathrm{b}}$ \\
\hline
\end{tabular}

$\mathrm{a}, \mathrm{b}$ - differences were significant between breeds in same $\kappa-\mathrm{CN}$ genotype $(\mathrm{p}<0.05)$. 
Milk compositions and milk coagulation properties according to $\beta$-LG

\begin{tabular}{|c|c|c|c|c|}
\hline \multirow{2}{*}{ Trait } & \multicolumn{2}{|c|}{ Latvian Brown } & \multicolumn{2}{|c|}{ Latvian Blue } \\
\hline & $\mathrm{AB}(\mathrm{n}=7)$ & $\mathrm{BB}(\mathrm{n}=46)$ & $\mathrm{AB}(\mathrm{n}=5)$ & $\mathrm{BB}(\mathrm{n}=17)$ \\
\hline Milk yield, $\mathrm{kg}$ & $18.5 \pm 1.33$ & $19.6 \pm 0.93$ & $18.0 \pm 1.76$ & $17.3 \pm 1.57$ \\
\hline Fat, $\mathrm{g} \mathrm{kg}^{-1}$ & $37.9 \pm 4.46^{\mathrm{a}, \mathrm{A}}$ & $45.5 \pm 1.37^{\mathrm{a}, \mathrm{B}}$ & $25.8 \pm 5.22^{\mathrm{b}, \mathrm{A}}$ & $37.9 \pm 2.39^{\mathrm{b}, \mathrm{B}}$ \\
\hline Protein, $\mathrm{g} \mathrm{kg}^{-1}$ & $34.2 \pm 1.09$ & $34.6 \pm 0.55$ & $33.7 \pm 1.98$ & $35.3 \pm 1.19$ \\
\hline Density, $\mathrm{kg} \mathrm{m}^{-3}$ & $1027.9 \pm 0.14^{\mathrm{a}}$ & $1028.5 \pm 0.20$ & $1030.4 \pm 1.29^{b}$ & $1028.7 \pm 0.42$ \\
\hline Curd firmness, $\mathrm{N}$ & $3.79 \pm 0.44$ & $3.25 \pm 0.19$ & $2.58 \pm 0.52$ & $3.24 \pm 0.27$ \\
\hline Curd yield, $\%$ & $22.9 \pm 2.03$ & $24.1 \pm 0.89$ & $19.3 \pm 1.73$ & $24.1 \pm 1.16$ \\
\hline Milk renneting time, $\min$ & $14.6 \pm 2.76^{\mathrm{a}}$ & $17.1 \pm 1.39$ & $21.7 \pm 10.35^{\mathrm{b}}$ & $17.4 \pm 2.84$ \\
\hline Protein to fat ratio & $0.96 \pm 0.08$ & $0.77 \pm 0.03^{\mathrm{a}}$ & $1.60 \pm 0.39^{\mathrm{A}}$ & $1.01 \pm 0.08^{\mathrm{b}, \mathrm{B}}$ \\
\hline
\end{tabular}

$\mathrm{a}, \mathrm{b}$ - differences were significant between breeds in same $\beta$-LG genotype $(\mathrm{p}<0.05)$.

A,B - differences were significant between $\beta-L G$ genotypes in same breed $(p<0.05)$.

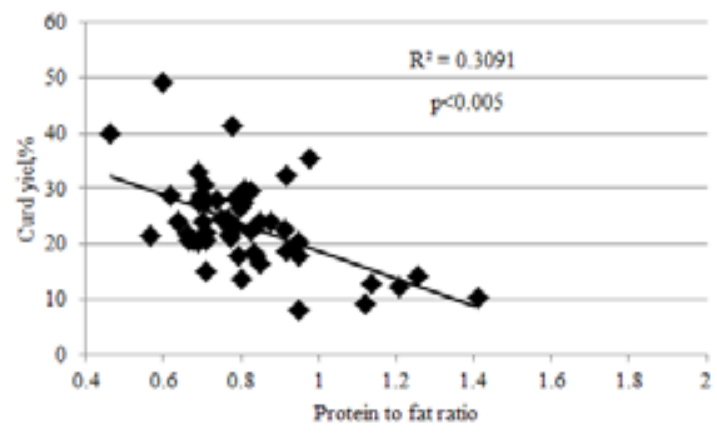

A

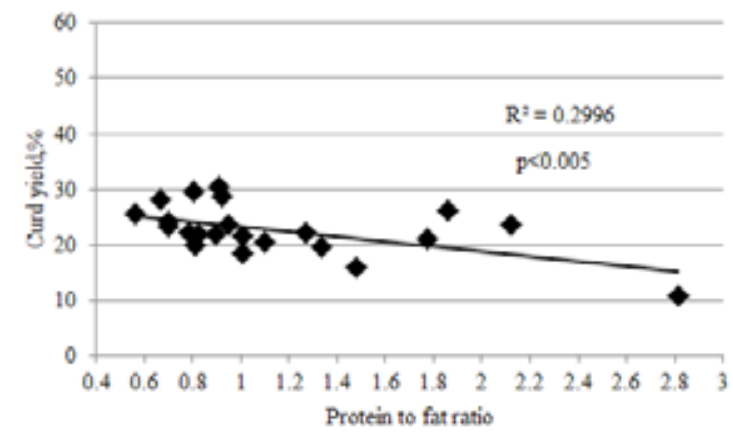

B

Figure 1. Relationships between milk protein to fat ratio and curd yield: A - Latvian Brown and B - Latvian Blue breed.

and co-authors (2013), medium strong to no positive relationships were obtained between protein to fat ratio and curd yield $\left(\mathrm{r}_{\mathrm{p}}=-0.67\right)$.

More extensive studies of milk coagulation properties could improve the knowledge about the Latvian local dairy breed and its milk perspectives for cheese making. Our results revealed $\mathrm{BB}$ and $\mathrm{AB}$ genotypes of $\kappa-\mathrm{CN}$ and $\beta-\mathrm{LG}$ positive effect on milk composition and coagulation properties. Therefore, for a better understanding and explanation of breed and genotype potential for cheese making further studies on milk protein profiles and genetic variants of different protein fractions during different seasons should be done.

\section{Conclusions}

Widespread $\kappa-\mathrm{CN}$ genotype was AA in LB breed and $\mathrm{AB}$ in $\mathrm{LZ}$ breed with frequencies 0.593 and 0.636 , while the highest frequencies of $\beta-L G$ was BB genotype.
Significant differences were observed in fat content - the highest fat content was in LB milk samples, accordingly, $\kappa-\mathrm{CN}$ was from AA genotype $46.3 \pm 1.89 \mathrm{~g} \mathrm{~kg}^{-1}-$ and $45.5 \pm 1.37 \mathrm{~g} \mathrm{~kg}^{-1}$ from BB $\beta$-LG genotype $(\mathrm{p}<0.05)$.

Significantly shorter milk renneting time of $\beta$-LG was obtained from LB breed $(14.6 \pm 2.76 \mathrm{~min}, \mathrm{p}<$ 0.05 ), while $\kappa-\mathrm{CN}$ genotype did not significantly affect this parameter.

A significantly higher curd yield was observed from BB $\kappa-C N$ genotype - on average $28 \%$, while $\beta$-LG genotype did not affect the curd yield significantly, however, the highest curd yield was obtained from BB genotypes in both breeds.

\section{Acknowledgment}

The research is supported by State Research Program AgroBioRes 3 project (LIVESTOCK). 


\section{References}

1. Aleandri, R., Buttazzoni, L.G., Schneider, J.C., Caroli, A., \& Davoli, R. (1990). The effects of milk protein polymorphisms on milk components and cheese-producing ability. Journal of Dairy Science. 73 (2), 241 - 255. DOI: 10.3168/jds.S0022-0302 (90)78667-5.

2. Aleandri, R., Schneider, J.S., \& Buttazzoni, L.G. (1989). Evaluation of milk for cheese production based on milk characteristics and Formagraph measures. Journal of Dairy Sciences. 72, 1967 - 1989. DOI: 10.3168/jds.S0022-0302(89)79319-X.

3. Alexander, L.J., Stewart, A.F., Mackinlay, A.G., Kapelinskaya, T.V., Tkach, T.M., \& Gorodetsky, S.I. (1988). Isolation and charactization of the bovine K-casein gene. Europian Journal of Biochemistry. 178, 395 - 401. DOI: 10.1111/j.1432-1033.1988.tb14463.x.

4. Bojanić-Rašović, M., Nikolić, N., Martinović, A., Katić, V., Rašović, R., Walcer, M., \& Domig, K. (2013). Correlation between protein to fat ratio of milk and chemical parameters and the yield of semi-hard cheese. Biotechnology in Animal Husbandry. 29 (1), p. 145 - 159. DOI: 10.2298/BAH1301145B.

5. Davoli, R., Dall'Olio, S., \& Russo, V. (1990). Effect of k-casein genotype on the coagulation properties of milk. Journal of Animal Breeding and Genetics. 107 (6), 458 - 464. DOI: 10.1111/j.1439-0388.1990. tb00058.x.

6. Eenennaam Van, A., \& Medrano, J.F. (1991). Milk protein polymorphisms in California dairy cattle. Journal of Dairy Science. 74, 1730 - 1742. DOI: 10.3168/jds.S0022-0302(91)78336-7.

7. De Marchi, M., Bittante, G., Dal Zotto, R., Dalvit, C., \& Cassandro, M. (2008). Effect of Holstein Friesian and Brown Swiss breeds on quality of milk and cheese. Journal of Dairy Science, 91, p. 4092 - 4102. DOI: 10.3168/jds.2007-0788.

8. Flower, D.R. (1996). The lipocalin protein family: structure and function. Biochemical Journal. 318 (1), 1 - 14. DOI: $10.1042 / \mathrm{bj} 3180001$.

9. Flower, D.R., North, A.C., \& Sansom, C.E., (2000). The lipocalin protein family: structural and sequence overview. Biochimica et Biophysica Acta (BBA) - Protein Structure and Molecular Enzymology. 1482 (12), 9 - 24. DOI: 10.1016/S0167-4838(00)00148-5.

10. Guinee, C.T.P., Mulholland, E.O., Kelly, J., \& Callaghan, D.J.O. (2007). Effect of protein-to-fat ratio of milk on the composition, manufacturing efficiency, and yield of cheddar cheese. Journal of dairy science, 90, 110 - 123. DOI: 10.3168/jds.S0022-0302(07)72613-9.

11. Ikonen, T., Ahlfors, K., Kempe, R., Ojala, M., \& Ruottinen, O. (1999). Genetic Parameters for the Milk Coagulation Properties and Prevalence of Noncoagulating Milk in Finnish Dairy Cows. Journal of Dairy Science. 82, 205 - 214. DOI: 10.3168/jds.S0022-0302(99)75225-2.

12. Jasińska, M., Dmytrów, I., Mituniewicz-Małek, A., \& Wąsik, K. (2010). Cow feeding system versus milk utility for yoghurt manufacture. Acta Sci. Pol., Technol. Aliment. 9, $189-199$.

13. Kontopidis, G., Holt, C., \& Sawyer, L. (2004). Invited Review: Beta-Lactoglobulin: Binding Properties, Structure, and Function. Journal of Dairy Science. 87 (4), 785 - 796. DOI: 10.3168/jds.S00220302(04)73222-1.

14. Kučerová, J., Matějíček, A., Jandurová, O.M., Sørensen, P., Němcová, E., Štípková, M., Kott, T., Bouška, J., \& Frelich, J. (2006). Milk protein genes CSN1S1, CSN2, CSN3, LGB and their relation to genetic values of milk production parameters in Czech Fleckvieh. Czech Journal of Animal Science. 51 (6), $241-247$.

15. Lindström, U.B., Antila, V., \& Syväjarvi, J. (1984). A note on some genetic and non-genetic factors affecting clotting time of Ayrshire milk. Acta Agriculturae Scandinavica. 34 (3), 349 - 355. DOI: 10.1080/00015128409435403.

16. Lunden, A., Nilsson, M., \& Janson, L. (1997). Marked effect of b-lactoglobulin polymorphism on the ratio of casein to total protein in milk. Journal of Dairy Science. 80, 2996 - 3005. DOI: 10.3168/jds.S00220302(97)76266-0.

17. Marchi, M., De Penasa, M., Tiezzi, F., Toffanin, V., \& Cassandro, M. (2013). Prediction of milk coagulation properties by Fourier Transform Mid-Infrared Spectroscopy (FTMIR) for genetic purposes, herd management and dairy profitability. ICAR Technical Series. 16, 47 - 53.

18. Martin, B., Chamba, J.F., Coulon, J.B., \& Perreard, E. (1997). Effect of milk chemical composition and clotting characteristics on chemical and sensory properties of Reblochon de Savoie cheese. Journal of Dairy Researches. 64, 157 - 162. DOI: 10.1017/S0022029996001975.

19. Matějičck, A., Matějičková, J., Štípková, M., Hanuš, O., Genčurová, V., Kysel’ová, J., Němcová, E., Kott, T., Šefrová, J., Krejčová, M., Melčová, S., Hölzelová, I., Bouška, J., \& Frelich, J. (2008). Joint effects of 
CSN3 and LGB genes on milk quality and coagulation properties in Czech Fleckvieh. Czech J. Anim. Sci., $53,246-252$.

20. Medrano, J.F., \& Aguilar-Cordova, E. (1990). Polymerase Chain Reaction Amplification of Bovine $\beta$ - Lactoglobulin Genomic Sequences and Identification of Genetic Variants by RFLP Analysis. Animal Biotechnology. 1, p. $73-77$.

21. Ng-Kwai-Hang, K.F., Hayes, J.F., Moxley, F.E., \& Monardes, H.G. (1986). Relationships between milk protein polymorphisms and major milk constituents in Holstein-Friesian cows. Journal of Dairy Science. 69, 22 - 26. DOI: 10.3168/jds.S0022-0302(86)80364-2.

22. Ng-Kwai-Hang, K.F., Hayes, J.F., Moxley, J.E., \& Monardes, H.G. (1984). Association of genetic variants of casein and milk serum proteins milk, fat, and protein production in dairy cattle. Journal of Dairy Science. 67, 835 - 840. DOI: 10.3168/jds.S0022-0302 (84)81374-0.

23. Ng-Kwai-Hang, K.F., Monardes, H.G., \& Hayes, J.F. (1990). Association between genetic polymorphism of milk proteins and production traits during three lactations. Journal of Dairy Science. 73, $3414-3420$. DOI: 10.3168/jds.S0022-0302(90)79038-8.

24. Pärna, E., Kiiman, H., Vallas, M., Viinalass, H., \& Savel, O. (2007). Development of a breeding objective for Estonian Holstein cattle. Agricultural and Food Science. 16,212-221. DOI: 10.2137/145960607783328164.

25. Pečiulaitienė, N., Miceikienè, I., Mišeikienė, R., \& Kriauziene, J. (2007). Genetic factors influencing milk production traits in Lithuanian dairy cattle breeds. Zemèsukio Mokslai $32-38$.

26. Ren, D.X., Miao, S.Y., Chen, Y.L., Zou, C.X., Liang, X.W., \& Liu, J.X. (2011). Genotyping of the k-casein and $\beta$-lactoglobulin genes in Chinese Holstein, Jersey and water buffalo by PCR-RFLP. Journal of Genetics. 90, (1), $1-5$.

27. Qin, B.Y., Bewley, M.C., Creamer, L.K., Baker, E.N., \& Jameson, G.B. (1999). Functional implications of structural differences between variants A and B of bovine $\beta$-lactoglobulin. Protein Science. 8 (1), 75 - 83. DOI: $10.1110 / \mathrm{ps} .8 .1 .75$.

28. Schaar, J., Hansson, B., \& Pettersson, H.E. (1985). Effects of genetic variants of $\kappa$-casein and $\beta$-lactoglobulin on cheesemaking. Journal of Dairy Research. 52 (3), 429 - 437. DOI: 10.1017/S002202990002433X.

29. Sturaro, A., Tiezzi, F., Penasa, M., De Marchi, M., \& Cassandro, M. (2012). Study of milk coagulation properties in multibreed Italian dairy herds. Acta argiculturae Slovenica. 3, 89-92.

30. Tsiaras, A.M., Bargouli, G.G., Banos, G., \& Boscos, C.M. (2005). Effect of kappa-casein and betalactoglobulin loci on milk production traits and reproductive performance of Holstein cows. Journal of Dairy Science. 88 (1), 327 - 334. DOI: 10.3168/jds.S0022-0302(05)72692-8.

31. Vallas, M., Bovenhuis, H., Kaart, T., Pärna, K., Kiiman, H., \& Pärna, E. (2010). Genetic parameters for milk coagulation properties in Estonian Holstein cows. Journal of Dairy Science. 93, 3789 - 3796 DOI: $10.3168 /$ jds.2009-2435.

32. Vallas, M., Kaart, T., Värv, S., Pärna K., Joũdu, I., Viinalass, H., \& Pärna, E. (2012). Composite $\beta$-к-casein genotypes and their effect on milk composition and coagulation of milk from Estonian Holstein cows. Journal of Dairy Science, 95, 6760 - 6769. DOI: 10.3168/jds.2012-5495.

33. Värv, S., Belousova, A., Sild, E., \& Viinalass, H. (2009). Genetic diversity in milk proteins among Estonian dairy cattle. Veterinarija ir Zootechnika. 48 (70), 93 - 98.

34. Velmala, R., Mantysaari, E.A., \& Maki-Tanila, A. (1995). Molecular genetic polymorphism at the k-casein and b-lactoglobulin loci in Finnish dairy bulls. Journal of Agricultural Science in Finland. 26, 431 - 435.

35. Wangdi, J., Dema, T., Karma, M., \& Bhujel, P. (2014). The compositional quality of cows milk in Bhutan. Issues in Biological Sciences and Pharmaceutical Research. 2, $62-68$.

36. Wedholm, A., Larsen, L.B., Lindmark-Mansson, H., Karlsson, A.H., \& Andren, A. (2006). Effect of protein composition on the cheesemaking properties of milk from individual dairy cows. Journal of Dairy Science. 89, 3296 - 3305. DOI: 10.3168/jds.S0022-0302(06)72366-9.

37. Zaglool, A.W., Awad, A., El Araby, I.E., \& El-Bayomi, K.M. (2016). Association of $\beta$-Lactoglobulin Gene Polymorphism with Milk Yield, Fat and Protein in Holstein-Friesian Cattle. World Veterinary Journal. 6, $117-122$.

38. Zannoni, M., Annibaldi, S. (1981). Standardization of the renneting ability of milk by Formagraph. Scienza e Tecnica Lattiero-Casearia 32, 79 - 94. 